\title{
Obesity and Kidney Disease: Hidden Consequences of the Epidemic
}

\author{
Csaba P. Kovesdy ${ }^{a, b}$ Susan L. Furth ${ }^{c}$ Carmine Zoccalid \\ on behalf of the World Kidney Day Steering Committee \\ ${ }^{a}$ Division of Nephrology, Department of Medicine, University of Tennessee Health Science Center \\ ${ }^{b}$ Nephrology Section, Memphis VA Medical Center, Memphis, TN, and ${ }^{c}$ Department of Pediatrics, Perelman School of \\ Medicine at the University of Pennsylvania, Philadelphia, PA, USA; ${ }^{d}$ CNR-IFC Clinical Epidemiology and \\ Pathophysiology of Renal Diseases and Hypertension, Reggio Calabria, Italy
}

\section{Key Words}

Obesity $\cdot$ Chronic kidney disease $\cdot$ Nephrolithiasis $\cdot$ Kidney

cancer · Prevention

\begin{abstract}
Obesity has become a worldwide epidemic, and its prevalence has been projected to grow by $40 \%$ in the next decade. This increasing prevalence has implications for the risk of diabetes, cardiovascular disease, and also for chronic kidney disease. A high body mass index is one of the strongest risk factors for new-onset chronic kidney disease. In individuals affected by obesity, a compensatory hyperfiltration occurs to meet the heightened metabolic demands of the increased body weight. The increase in intraglomerular pressure can damage the kidneys and raise the risk of developing chronic kidney disease in the long-term. The incidence of obesityrelated glomerulopathy has increased 10 -fold in recent years. Obesity has also been shown to be a risk factor for nephrolithiasis, and for a number of malignancies including kidney cancer. This year, the World Kidney Day promotes education on the harmful consequences of obesity and its association with kidney disease, advocating healthy lifestyle and health policy measures that make preventive behaviors an affordable option.

c 2017 S. Karger AG, Basel
\end{abstract}

\section{KARGER}

(c) 2017 S. Karger AG, Basel

E-Mail karger@karger.com

www.karger.com/ajn

\section{Introduction}

In 2014, over 600 million adults worldwide, 18 years and older, were obese. Obesity is a potent risk factor for the development of kidney disease. It increases the risk of developing major risk factors for chronic kidney disease (CKD), like diabetes and hypertension, and it has a direct impact on the development of CKD and end-stage renal disease (ESRD). In individuals affected by obesity, a (likely) compensatory mechanism of hyperfiltration occurs to meet the heightened metabolic demands of the increased body weight. The increase in intraglomerular pressure can damage the kidney structure and raise the risk of developing CKD in the long-term.

The good news is that obesity, as well as the related CKD, are largely preventable. Education and awareness of the risks of obesity and a healthy lifestyle, including proper nutrition and exercise, can dramatically help in preventing obesity and kidney disease. This article reviews the association of obesity with kidney disease on the occasion of the 2017 World Kidney Day.

Members of the World Kidney Day Steering Committee are: Philip Kam Tao Li, Guillermo Garcia-Garcia, Mohammed Benghanem-Gharbi, Rik Bollaert, Sophie Dupuis, Timur Erk, Kamyar Kalantar-Zadeh, Csaba Kovesdy, Charlotte Osafo, Miguel C. Riella, Elena Zakharova. 


\section{Epidemiology of Obesity in Adults and Children}

Over the last 3 decades, the prevalence of overweight and obese adults (BMI $\geq 25)$ worldwide has increased substantially [1]. In the US, the age-adjusted prevalence of obesity in 2013-2014 was 35\% among men and 40.4\% among women [2]. The problem of obesity also affects children. In the US in 2011-2014, the prevalence of obesity was $17 \%$ and extreme obesity $5.8 \%$ among youth $2-19$ years of age. The rise in obesity prevalence is also a worldwide concern $[3,4]$, as it is projected to grow by $40 \%$ across the globe in the next decade. Low- and middleincome countries are now showing evidence of transitioning from normal weight to overweight and obesity as parts of Europe and the United States did decades ago [5]. This increasing prevalence of obesity has implications for cardiovascular disease (CVD) and also for CKD. A high body mass index (BMI) is one of the strongest risk factors for new-onset CKD $[6,7]$.

Definitions of obesity are most often based on BMI (i.e., weight [kilograms] divided by the square of his or her height [meters]). A BMI between 18.5 and 25 is considered by the World Health Organization (WHO) to be normal weight, a BMI between 25 and 30 as overweight, and a BMI of $>30$ as obese. Although BMI is easy to calculate, it is a poor estimate of fat mass distribution, as muscular individuals or those with more subcutaneous fat may have a BMI as high as individuals with larger intraabdominal (visceral) fat. The latter type of high BMI is associated with substantially higher risk of metabolic and cardiovascular disease. Alternative parameters to more accurately capture visceral fat include waist circumference (WC) and a waist-to-hip ratio (WHR) of $>102 \mathrm{~cm}$ and 0.9 , respectively, for men and $>88 \mathrm{~cm}$ and $>0.8$, respectively, for women. WHR has been shown to be superior to $\mathrm{BMI}$ for the correct classification of obesity in CKD.

\section{Association of Obesity with CKD and Other Renal Complications}

Numerous population-based studies have shown an association between measures of obesity and both the development and the progression of CKD (Table 1). Higher $\mathrm{BMI}$ is associated with the presence [8] and development [9-11] of proteinuria in individuals without kidney disease. Furthermore, in numerous large population-based studies, higher BMI appears associated with the presence $[8,12]$ and development of low estimated GFR $[9,10,13]$, with more rapid loss of estimated GFR over time [14], and with the incidence of ESRD [15-18]. Elevated BMI levels, class II obesity and above, have been associated with more rapid progression of $\mathrm{CKD}$ in patients with preexisting CKD [19]. A few studies examining the association of abdominal obesity using WHR or WC with CKD describe an association between higher girth and albuminuria [20], decreased GFR [8] or incident ESRD [21] independent of BMI level.

Higher visceral adipose tissue measured by computed tomography has been associated with a higher prevalence of albuminuria in men [22]. The observation of a BMIindependent association between abdominal obesity and poorer renal outcomes is also described in relationship with mortality in patients with ESRD [23] and kidney transplant [24], and suggests a direct role of visceral adiposity. In general, the associations between obesity and poorer renal outcomes persist even after adjustments for possible mediators of obesity's cardiovascular and metabolic effects, such as high blood pressure and diabetes mellitus, suggesting that obesity may affect kidney function through mechanisms in part unrelated to these complications (vide infra).

The deleterious effect of obesity on the kidneys extends to other complications such as nephrolithiasis and kidney malignancies. Higher BMI is associated with an increased prevalence [25] and incidence [26, 27] of nephrolithiasis. Furthermore, weight gain over time, and higher baseline WC were also associated with higher incidence of nephrolithiasis [27]. Obesity is associated with various types of malignancies, particularly cancers of the kidneys. In a population-based study of 5.24 million individuals from the UK, a 5 higher BMI was associated with a $25 \%$ higher risk of kidney cancers, with $10 \%$ of all kidney cancers attributable to excess weight [28]. Another large analysis examining the global burden of obesity on malignancies estimated that 17 and $26 \%$ of all kidney cancers in men and women, respectively, were attributable to excess weight [29]. The association between obesity and kidney cancers was consistent in both men and women, and across populations from different parts of the world in a meta-analysis that included data from 221 studies (of which 17 examined kidney cancers) [30]. Among the cancers examined in this meta-analysis, kidney cancers had the third highest risk associated with obesity (relative risk per 5 higher BMI: 1.24, 95\% CI 1.20 $1.28, p<0.0001)[30]$. 
Table 1. Studies examining the association of obesity with various measures of CKD

\begin{tabular}{|c|c|c|c|c|c|}
\hline Study & Patients & Exposure & Outcomes & Results & Comments \\
\hline $\begin{array}{l}\text { Prevention of Renal and } \\
\text { Vascular End-Stage } \\
\text { Disease (PREVEND) } \\
\text { Study [8] }\end{array}$ & $\begin{array}{l}7,676 \text { Dutch } \\
\text { individuals without } \\
\text { diabetes }\end{array}$ & $\begin{array}{l}\text { Elevated BMI } \\
\left(\text { overweight and }^{\text {a }}\right. \\
\text { obese }^{\mathrm{a}} \text {, and central } \\
\text { fat distribution } \\
\text { (WHR) }\end{array}$ & $\begin{array}{l}\text { Presence of urine } \\
\text { albumin } 30-300 \mathrm{mg} / 24 \\
\mathrm{~h} \\
\text { Elevated and diminished } \\
\text { GFR }\end{array}$ & $\begin{array}{l}\text { Obese }+ \text { central fat: higher risk of } \\
\text { albuminuria } \\
\text { Obese } \pm \text { central fat: higher risk of } \\
\text { elevated GFR } \\
\text { Central fat } \pm \text { obesity associated } \\
\text { with diminished filtration }\end{array}$ & Cross-sectional analysis \\
\hline $\begin{array}{l}\text { Multinational study of } \\
\text { hypertensive outpatients } \\
\text { [20] }\end{array}$ & $\begin{array}{l}20,828 \text { patients from } \\
26 \text { countries }\end{array}$ & BMI and WC & $\begin{array}{l}\text { Prevalence of } \\
\text { albuminuria by dip stick }\end{array}$ & $\begin{array}{l}\text { Higher WC associated with } \\
\text { albuminuria independent of BMI }\end{array}$ & Cross-sectional analysis \\
\hline $\begin{array}{l}\text { Framingham Multi- } \\
\text { Detector Computed } \\
\text { Tomography (MDCT) } \\
\text { cohort [22] }\end{array}$ & 3,099 individuals & $\begin{array}{l}\text { Visceral adipose } \\
\text { tissue (VAT) and } \\
\text { subcutaneous adipose } \\
\text { tissue }\end{array}$ & $\begin{array}{l}\text { Prevalence of UACR }>25 \\
\mathrm{mg} / \mathrm{g} \text { in women and }>17 \\
\mathrm{mg} / \mathrm{g} \text { in men }\end{array}$ & $\begin{array}{l}\text { VAT associated with albuminuria } \\
\text { in men, but not in women }\end{array}$ & Cross-sectional analysis \\
\hline $\begin{array}{l}\text { CARDIA (Coronary } \\
\text { Artery Risk Development } \\
\text { in Young Adults) } \\
\text { study[11] }\end{array}$ & $\begin{array}{l}2,354 \text { community- } \\
\text { dwelling individuals } \\
\text { with normal kidney } \\
\text { function aged } 28-40 \\
\text { years }\end{array}$ & $\begin{array}{l}\text { Obesity }(\mathrm{BMI}>30) \\
\text { Diet and lifestyle- } \\
\text { related factors }\end{array}$ & $\begin{array}{l}\text { Incident } \\
\text { microalbuminuria }\end{array}$ & $\begin{array}{l}\text { Obesity (OR 1.9) and unhealthy } \\
\text { diet (OR 2.0) associated with } \\
\text { incident albuminuria }\end{array}$ & Low number of events \\
\hline $\begin{array}{l}\text { Hypertension Detection } \\
\text { and Follow-Up Program } \\
{[10]}\end{array}$ & $\begin{array}{l}5,897 \text { hypertensive } \\
\text { adults }\end{array}$ & $\begin{array}{l}\text { Overweight and obese } \\
\mathrm{BMI}^{\mathrm{a}} \text { vs. normal BMI }\end{array}$ & $\begin{array}{l}\text { Incident CKD }(1+\text { or } \\
\text { greater proteinuria on } \\
\text { urinalysis and/or an } \\
\text { eGFR }<60 \mathrm{~mL} / \mathrm{min} / 1.73 \\
\left.\mathrm{~m}^{2}\right)\end{array}$ & $\begin{array}{l}\text { Both overweight (OR 1.21) and } \\
\text { obesity (OR 1.40) associated with } \\
\text { incident CKD }\end{array}$ & $\begin{array}{l}\text { Results unchanged after excluding } \\
\text { diabetics }\end{array}$ \\
\hline $\begin{array}{l}\text { Framingham Offspring } \\
\text { Study [9] }\end{array}$ & $\begin{array}{l}2,676 \text { individuals free } \\
\text { of CKD stage } 3\end{array}$ & High vs. normal BMI ${ }^{\mathrm{a}}$ & $\begin{array}{l}\text { Incident CKD stage } 3 \\
\text { Incident proteinuria }\end{array}$ & $\begin{array}{l}\text { Higher BMI not associated with } \\
\text { CKD3 after adjustments } \\
\text { Higher BMI associated with } \\
\text { increased odds of incident } \\
\text { proteinuria }\end{array}$ & $\begin{array}{l}\text { Predominantly white, limited } \\
\text { geography }\end{array}$ \\
\hline $\begin{array}{l}\text { Physicians' Health Study } \\
\text { [13] }\end{array}$ & $\begin{array}{l}11,104 \text { initially } \\
\text { healthy men in USA }\end{array}$ & $\begin{array}{l}\text { BMI quintiles } \\
\text { Increase in BMI over } \\
\text { time (vs. stable BMI) }\end{array}$ & $\begin{array}{l}\text { Incident eGFR }<60 \mathrm{~mL} / \\
\mathrm{min} / 1.73 \mathrm{~m}^{2}\end{array}$ & $\begin{array}{l}\text { Higher baseline BMI and increase } \\
\text { in BMI over time both associated } \\
\text { with higher risk of incident CKD }\end{array}$ & Exclusively men \\
\hline $\begin{array}{l}\text { Nationwide US Veterans } \\
\text { Administration cohort } \\
{[14]}\end{array}$ & $\begin{array}{l}3,376,187 \text { USA } \\
\text { veterans with } \\
\text { baseline eGFR } \geq 60 \\
\mathrm{~mL} / \mathrm{min} / 1.73 \mathrm{~m}^{2}\end{array}$ & $\begin{array}{l}\text { BMI categories from } \\
<20 \text { to }>50\end{array}$ & $\begin{array}{l}\text { Rapid decline in kidney } \\
\text { function (negative eGFR } \\
\text { slope of }>5 \mathrm{~mL} / \mathrm{min} / 1.73 \\
\mathrm{~m}^{2} \text { ) }\end{array}$ & $\begin{array}{l}\text { BMI }>30 \text { associated with rapid loss } \\
\text { of kidney function }\end{array}$ & $\begin{array}{l}\text { Associations more accentuated in } \\
\text { older individuals }\end{array}$ \\
\hline $\begin{array}{l}\text { Nationwide population- } \\
\text { based study from Sweden } \\
{[12]}\end{array}$ & $\begin{array}{l}926 \text { Swedes with } \\
\text { moderate/advanced } \\
\text { CKD compared to } \\
998 \text { controls }\end{array}$ & $\mathrm{BMI} \geq 25$ vs. $<25$ & CKD vs. no CKD & $\begin{array}{l}\text { Higher BMI associated with } 3 \times \\
\text { higher risk of CKD }\end{array}$ & $\begin{array}{l}\text { Risk strongest in diabetics, but also } \\
\text { significantly higher in nondiabetics } \\
\text { Cross-sectional analysis }\end{array}$ \\
\hline $\begin{array}{l}\text { Nationwide population } \\
\text { based study in Israel [17] }\end{array}$ & $\begin{array}{l}1,194,704 \text { adolescent } \\
\text { males and females } \\
\text { examined for } \\
\text { military service }\end{array}$ & $\begin{array}{l}\text { Elevated BMI } \\
\text { (overweight and } \\
\text { obesity) vs. normal } \\
\text { BMI }^{\mathrm{a}}\end{array}$ & Incident ESRD & $\begin{array}{l}\text { Overweight (HR 3.0) and obesity } \\
\text { (HR 6.89) associated with higher } \\
\text { risk of ESRD }\end{array}$ & $\begin{array}{l}\text { Associations strongest for diabetic } \\
\text { ESRD, but also significantly higher } \\
\text { for non-diabetic ESRD }\end{array}$ \\
\hline $\begin{array}{l}\text { The Nord-Trøndelag } \\
\text { Health Study (HUNT-1) } \\
{[15]}\end{array}$ & $\begin{array}{l}74,986 \text { Norwegian } \\
\text { adults }\end{array}$ & BMI categories ${ }^{\mathrm{a}}$ & $\begin{array}{l}\text { Incidence of ESRD or } \\
\text { renal death }\end{array}$ & $\begin{array}{l}\text { BMI }>30 \text { associated with worse } \\
\text { outcomes }\end{array}$ & $\begin{array}{l}\text { Associations not present in } \\
\text { individuals with } \mathrm{BP}<120 / 80 \mathrm{~mm} \\
\mathrm{Hg}\end{array}$ \\
\hline $\begin{array}{l}\text { Community-based } \\
\text { screening in Okinawa, } \\
\text { Japan [16] }\end{array}$ & $\begin{array}{l}100,753 \text { individuals } \\
>20 \text { years old }\end{array}$ & BMI quartiles & Incidence of ESRD & $\begin{array}{l}\text { Higher BMI associated with } \\
\text { increased risk of ESRD in men, but } \\
\text { not in women }\end{array}$ & $\begin{array}{l}\text { Average BMI lower in Japan } \\
\text { compared to Western countries }\end{array}$ \\
\hline $\begin{array}{l}\text { Nationwide US Veterans } \\
\text { Administration cohort } \\
{[19]}\end{array}$ & $\begin{array}{l}453,946 \text { USA } \\
\text { veterans with } \\
\text { baseline eGFR }<60 \\
\mathrm{ml} / \mathrm{min} \text { per } 1.73 \mathrm{~m}^{2}\end{array}$ & $\begin{array}{l}\text { BMI categories from } \\
<20 \text { to }>50\end{array}$ & $\begin{array}{l}\text { Incidence of ESRD } \\
\text { Doubling of serum } \\
\text { creatinine } \\
\text { Slopes of eGFR }\end{array}$ & $\begin{array}{l}\text { Moderate and severe obesity } \\
\text { associated with worse renal } \\
\text { outcomes }\end{array}$ & $\begin{array}{l}\text { Associations present but weaker in } \\
\text { patients with more advanced CKD }\end{array}$ \\
\hline $\begin{array}{l}\text { Kaiser Permanente } \\
\text { Northern California [18] }\end{array}$ & $\begin{array}{l}320,252 \text { adults with } \\
\text { and without baseline } \\
\text { CKD }\end{array}$ & $\begin{array}{l}\text { Overweight, class I, II } \\
\text { and extreme obesity; } \\
\text { vs. normal BMI }\end{array}$ & Incidence of ESRD & $\begin{array}{l}\text { Linearly higher risk of ESRD with } \\
\text { higher BMI categories }\end{array}$ & $\begin{array}{l}\text { Associations remained present after } \\
\text { adjustment for DM, hypertension } \\
\text { and baseline CKD }\end{array}$ \\
\hline $\begin{array}{l}\text { REGARDS (Reasons for } \\
\text { Geographic and Racial } \\
\text { Differences in Stroke) } \\
\text { study [21] }\end{array}$ & 30,239 individuals & Elevated WC or BMI & Incidence of ESRD & $\begin{array}{l}\text { BMI above normal not associated } \\
\text { with ESRD after adjustment for } \\
\text { WC } \\
\text { Higher WC associated with ESRD }\end{array}$ & $\begin{array}{l}\text { Association of WC with ESRD } \\
\text { became on-significant after } \\
\text { adjustment for comorbidities and } \\
\text { baseline eGFR and proteinuria }\end{array}$ \\
\hline
\end{tabular}

BMI, body mass index; CKD, chronic kidney disease; DM, diabetes mellitus; eGFR, estimated glomerular filtration rate; ESRD, end-stage renal disease; HR, hazard ratio; OR, odds ratio; UACR, urine albumin-creatinine ratio; WC, waist circumference; WHR, waist-to-hip ratio; BP, blood pressure.

${ }^{a}$ Normal weight: BMI 18.5-24.9; overweight: BMI 25.0-29.9; class I obesity: BMI 30.0-34.9; class II obesity: BMI 35.0-39.9; class III obesity: BMI $\geq 40$. 


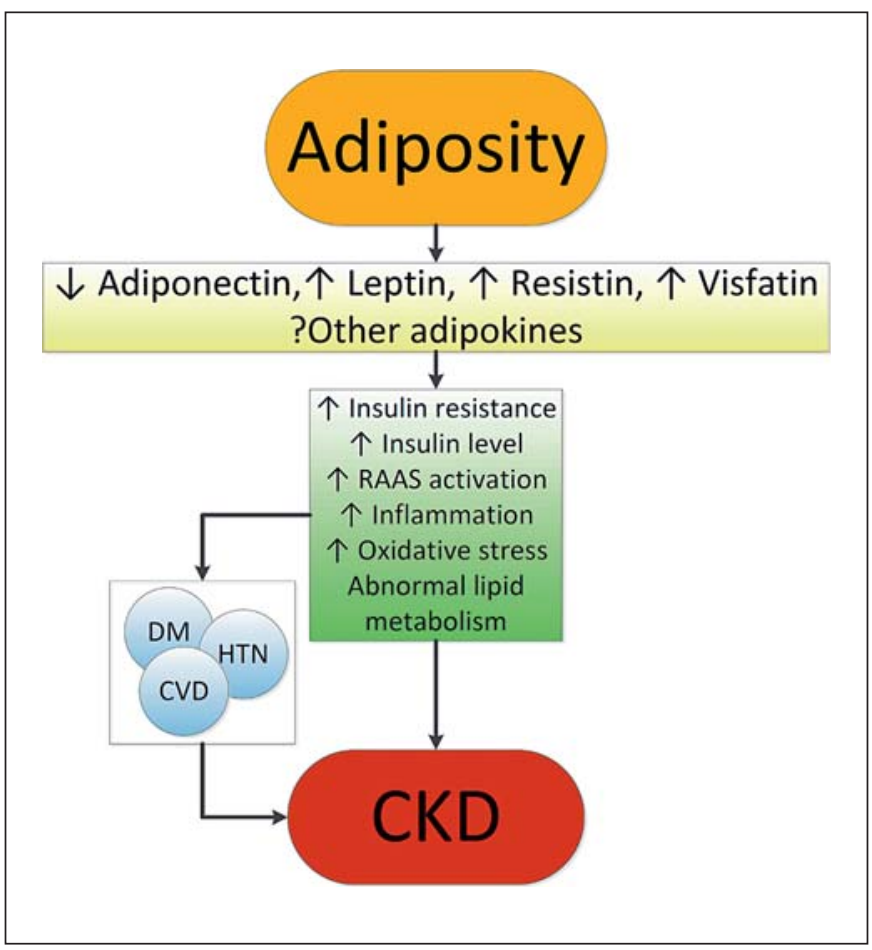

Fig. 1. Putative mechanisms of action, whereby obesity causes CKD.

\section{Mechanisms of Action Underlying the Renal Effects of Obesity}

Obesity results in complex metabolic abnormalities which have wide-ranging effects on diseases affecting the kidneys. The exact mechanisms whereby obesity may worsen or cause CKD remain unclear. The fact that most obese individuals never develop CKD, and the distinction of up to as many as $25 \%$ of obese individuals as "metabolically healthy" suggests that increased weight alone is not sufficient to induce kidney damage [31]. Some of the deleterious renal consequences of obesity may be mediated by downstream comorbid conditions such as diabetes mellitus or hypertension, but there are also effects of adiposity which could impact the kidneys directly, induced by the endocrine activity of the adipose tissue via production of (among others) adiponectin [32], leptin [33], and resistin [34] (Fig. 1). These include the development of inflammation [35], oxidative stress [36], abnormal lipid metabolism [37], activation of the renin-angiotensin-aldosterone system [38], and increased production of insulin and insulin resistance $[39,40]$.

These various effects result in specific pathologic changes in the kidneys [41] which could underlie the

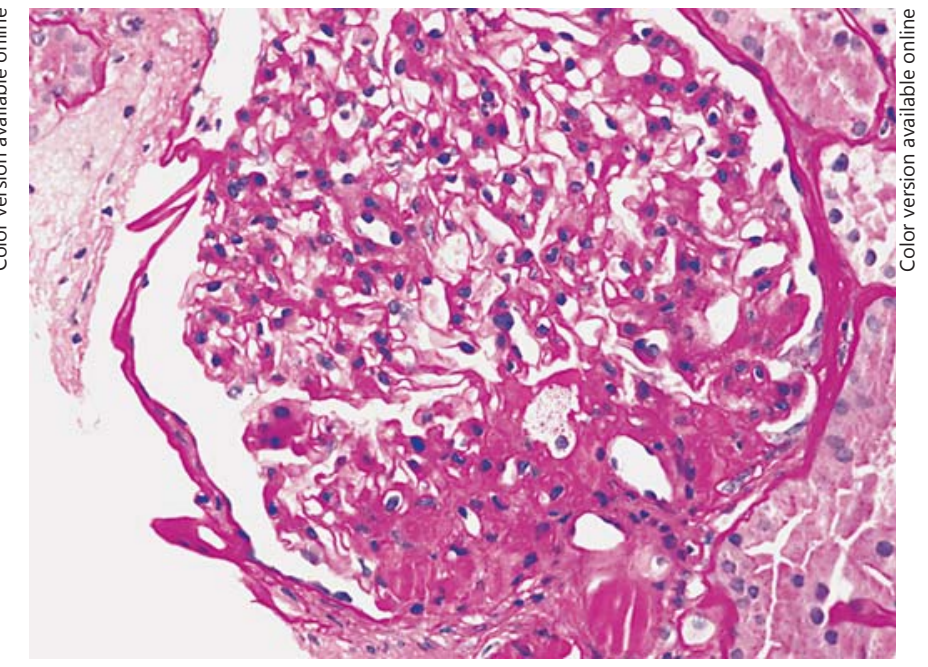

Fig. 2. Obesity-related perihilar focal segmental glomerulosclerosis on a background of glomerulomegaly. Periodic acid-Schiff stain. Original magnification $\times 400$. Courtesy of Dr. Patrick D. Walker, MD; Arkana Laboratories, Little Rock, AR, USA.

higher risk of CKD seen in observational studies. These include ectopic lipid accumulation [42] and increased deposition of renal sinus fat $[43,44]$, the development of glomerular hypertension and increased glomerular permeability caused by hyperfiltration-related glomerular filtration barrier injury [45], and ultimately the development of glomerulomegaly [46], and focal or segmental glomerulosclerosis [41] (Fig. 2). The incidence of the socalled obesity-related glomerulopathy (ORG) has increased 10-fold between 1986 and 2000 [41]. Importantly, ORG often presents along with pathophysiologic processes related to other conditions or advanced age, conspiring to result in more accentuated kidney damage in patients with high blood pressure [47] or in the elderly $[14,39]$.

Obesity is associated with a number of risk factors contributing to the higher incidence and prevalence of nephrolithiasis. Higher body weight is associated with lower urine $\mathrm{pH}$ [48] and increased urinary oxalate [49], uric acid, sodium and phosphate excretion [50]. Diets richer in protein and sodium may lead to a more acidic urine and decrease in urinary citrate, also contributing to kidney stone risk. The insulin resistance characteristic of obesity may also predispose to nephrolithiasis [51] through its impact on tubular $\mathrm{Na}-\mathrm{H}$ exchanger [52] and ammoniagenesis [53], and the promotion of an acidic milieu [54]. Complicating the picture is the fact that some weight loss therapies result in a worsening, rather than an 
improvement in the risk for kidney stone formation; e.g., gastric surgery can lead to a substantial increase in enteral oxalate absorption and enhanced risk of nephrolithiasis [55].

The mechanisms behind the increased risk of kidney cancers observed in obese individuals are less well characterized. Insulin resistance, and the consequent chronic hyperinsulinemia and increased production of insulinlike growth factor 1 and numerous complex secondary humoral effects may exert stimulating effects on the growth of various types of tumor cells [56]. More recently, the endocrine functions of adipose tissue [57], its effects on immunity [58], and the generation of an inflammatory milieu with complex effects on cancers $[59,60]$ have emerged as additional explanations.

\section{Obesity in Patients with Advanced Kidney Disease: The Need for a Nuanced Approach}

Considering the above evidence about the overwhelmingly deleterious effects of obesity on various disease processes, it is seemingly counterintuitive that obesity has been consistently associated with lower mortality rates in patients with advanced CKD $[19,61]$ and $\operatorname{ESRD}[62,63]$. Similar "paradoxical" associations have also been described in other populations, such as in patients with congestive heart failure [64], chronic obstructive pulmonary disease [65], rheumatoid arthritis [66], and even in old individuals [67]. It is possible that the seemingly protective effect of a high BMI is the result of the imperfection of BMI as a measure of obesity, as it does not differentiate the effects of adiposity from those of higher nonadipose tissue. Indeed, studies that separated the effects of a higher WC from those of higher BMI showed a reversal of the inverse association with mortality [23, 24]. Higher muscle mass has also been shown to explain at least some of the positive effects attributed to elevated BMI $[63,68]$. However, there is also evidence to suggest that higher adiposity, especially subcutaneous (nonvisceral) fat, may also be associated with better outcomes in ESRD patients [62]. Such benefits may indeed be present in patients who have very low short-term life expectancy, such as most ESRD patients [69]. Indeed, some studies that examined the association of BMI with time-dependent survival in ESRD have shown a marked contrast between protective shortterm effects versus deleterious longer-term effects of higher BMI [70]. There are several putative short-term benefits that higher body mass could portend, especially to sicker individuals. These include a benefit from the bet- ter nutritional status typically seen in obese individuals, and which provides better protein and energy reserves in the face of acute illness, and a higher muscle mass with enhanced antioxidant capacity [63] and lower circulating actin and higher plasma gelsolin levels [71], which are associated with better outcomes. Other hypothetically beneficial characteristics of obesity include: a more stable hemodynamic status with mitigation of stress responses and heightened sympathetic and renin-angiotensin activity [72]; increased production of adiponectins [73] and soluble tumor necrosis factor alfa receptors [74] by adipose tissue neutralizing the adverse effects of tumor necrosis factor alfa; enhanced binding of circulating endotoxins [75] by the characteristically higher cholesterol levels seen in obesity; and sequestration of uremic toxins by adipose tissue [76].

\section{Potential Interventions for Management of Obesity}

Obesity engenders kidney injury via direct mechanisms through deranged synthesis of various adipose tissue cytokines with nephrotoxic potential, as well as indirectly by triggering diabetes and hypertension, i.e. two conditions that rank among the strongest risk factors for CKD. Perhaps due to the survival advantage of obesity in $\mathrm{CKD}$, the prevalence of end-stage kidney disease is on the rise both in the USA [77] and in Europe [78]. Strategies for controlling the obesity-related CKD epidemic at population level and for countering the evolution of CKD toward kidney failure in obese patients represent the most tantalizing task that today's health planners, health managers, and nephrologists face.

\section{Countering CKD at Population Level}

Calls for public health interventions in the community to prevent and treat CKD at an early stage have been made by major renal associations, including the International Society of Nephrology (ISN), International Federation of the Kidney Foundation (IFKF), the European renal association (ERA-EDTA), and various national societies. In the USA, Healthy People 2020, a program that sets 10year health targets for health promotion and prevention goals, focuses on both CKD and obesity. Surveys to detect obese patients, particularly those with a high risk of CKD (e.g., hypertensive and/or diabetic obese people) and those receiving suboptimal care to inform these patients of the potential risk for CKD they are exposed to, is the first step towards developing public health interventions. Acquiring evidence that current interventions to reduce 
CKD risk in the obese are efficacious and deployable is an urgent priority to set goals and means for risk modification. Appropriate documentation of existing knowledge distilling the risk and the benefits of primary and secondary prevention interventions in obese people, and new trials in this population to fill knowledge gaps (see below) are needed. Finally, surveillance programs that monitor progress on the detection of at-risk individuals and the effectiveness of prevention programs being deployed [79] constitute the third, fundamental element for establishing efficacious CKD prevention plans at population level.

A successful surveillance system for CKD has already been implemented in some places such as the UK [80]. A campaign to disseminate and apply K-DOQI CKD guidelines in primary care within the UK National Health Service was launched. This progressively increased the adoption of K-DOQI guidelines and, also thanks to specific incentives for UK general physicians to detect CKD, led to an impressive improvement in the detection and care of CKD, i.e. better control of hypertension and increased use of angiotensin-converting enzyme and angiotensin receptor blockers [80]. This system may serve as a platform to improve the prevention of obesity-related CKD. Campaigns aiming at reducing the obesity burden are now at center stage worldwide and are strongly recommended by the WHO, and it is expected that these campaigns will reduce the incidence of obesity-related complications, including CKD. However obesity-related goals in obese CKD patients remain vaguely formulated, largely because of the paucity of high-level evidence intervention studies to modify obesity in CKD patients [81].

\section{Prevention of CKD Progression in Obese People with CKD}

Observational studies in metabolically healthy obese subjects show that the obese phenotype unassociated with metabolic abnormalities per se predicts a higher risk for incident CKD [82], suggesting that obesity per se may engender renal dysfunction and kidney damage even without diabetes or hypertension (vide supra). In overweight or obese diabetic patients, a lifestyle intervention including caloric restriction and increased physical activity compared with a standard follow-up based on education and support to sustain diabetes treatment reduced the risk for incident CKD by 30\%, although it did not affect the incidence of cardiovascular events [83]. Such a protective effect was partly due to reductions in body weight, $\mathrm{HbA1c}$, and systolic blood pressure. No safety concerns regarding kidney-related adverse events were seen [83]. In a recent meta-analysis collating experimental studies in obese CKD patients, interventions aimed at reducing body weight showed coherent reductions in blood pressure, glomerular hyperfiltration and proteinuria [81]. A thorough post hoc analysis of the REIN study showed that the nephron-protective effect of ACE inhibition in proteinuric CKD patients was maximal in obese CKD patients, but minimal in CKD patients with normal or low BMI [84]. Of note, bariatric surgical intervention has been suggested for selected CKD and ESRD patients including dialysis patients who are waitlisted for kidney transplantation [85-87].

Globally, these experimental findings provide a proof of concept for the usefulness of weight reduction and ACE inhibition interventions in the treatment of CKD in the obese. Studies showing a survival benefit of increased BMI in CKD patients, however, remain to be explained [88]. These findings limit our ability to make strong recommendations about the usefulness and the safety of weight reduction among individuals with more advanced stages of CKD. Lifestyle recommendations to reduce body weight in obese people at risk for CKD and in those with early CKD appear justified, particularly recommendations for the control of diabetes and hypertension. As the independent effect of obesity control on the incidence and progression of CKD is difficult to disentangle from the effects of hypertension and type 2 diabetes, a recommendation of weight loss in the minority of metabolically healthy, nonhypertensive obese patients remains unwarranted. These considerations suggest that a therapeutic approach to overweight and obesity in patients with advanced CKD or other significant comorbid conditions has to be pursued carefully, with proper considerations of the expected benefits and potential complications of weight loss over the life span of the individual patient.

\section{Conclusions}

The worldwide epidemic of obesity affects the Earth's population in many ways. Diseases of the kidneys, including CKD, nephrolithiasis, and kidney cancers are among the more insidious effects of obesity, but which nonetheless have wide ranging deleterious consequences, ultimately leading to significant excess morbidity and mortality and excess costs to individuals and the entire society. Population-wide interventions to control obesity could have beneficial effects in preventing the development, or delaying the progression of CKD. It is incumbent upon the entire healthcare community to devise 
long-ranging strategies towards improving the understanding of the links between obesity and kidney diseases, and to determine optimal strategies to stem the tide. The 2017 World Kidney Day is an important opportunity to increase education and awareness to that end.

\section{Conflict of Interest Statement}

The authors have no conflicts of interest to disclose.

\section{References}

1 Forouzanfar MH, Alexander L, Anderson HR, Bachman VF, et al: Global, regional, and national comparative risk assessment of 79 behavioural, environmental and occupation$\mathrm{al}$, and metabolic risks or clusters of risks in 188 countries, 1990-2013: a systematic analysis for the Global Burden of Disease Study 2013. Lancet 2015;386:2287-2323.

2 Flegal KM, Kruszon-Moran D, Carroll MD, Fryar CD, Ogden CL: Trends in obesity among adults in the United States, 2005 to 2014. JAMA 2016;315:2284-2291.

3 Cattaneo A, Monasta L, Stamatakis E, Lioret S, Castetbon K, Frenken F, Manios Y, Moschonis G, Savva S, Zaborskis A, Rito AI, Nanu M, Vignerova J, Caroli M, Ludvigsson J, Koch FS, Serra-Majem L, Szponar L, van LF, Brug J: Overweight and obesity in infants and preschool children in the European Union: a review of existing data. Obes Rev 2010;11:389398.

4 Olaya B, Moneta MV, Pez O, Bitfoi A, Carta MG, Eke C, Goelitz D, Keyes KM, Kuijpers R, Lesinskiene S, Mihova Z, Otten R, Fermanian C, Haro JM, Kovess V: Country-level and individual correlates of overweight and obesity among primary school children: a cross-sectional study in seven European countries. BMC Public Health 2015;15:475.

5 Subramanian SV, Perkins JM, Ozaltin E, Davey SG: Weight of nations: a socioeconomic analysis of women in low- to middle-income countries. Am J Clin Nutr 2011;93:413-421.

6 Tsujimoto T, Sairenchi T, Iso H, Irie F, Yamagishi K, Watanabe $\mathrm{H}$, Tanaka K, Muto T, Ota $\mathrm{H}$ : The dose-response relationship between body mass index and the risk of incident stage $\geq 3$ chronic kidney disease in a general Japanese population: the Ibaraki prefectural health study (IPHS). J Epidemiol 2014;24: 444-451.

7 Elsayed EF, Sarnak MJ, Tighiouart H, Griffith JL, Kurth T, Salem DN, Levey AS, Weiner DE: Waist-to-hip ratio, body mass index, and subsequent kidney disease and death. Am J Kidney Dis 2008;52:29-38.

8 Pinto-Sietsma SJ, Navis G, Janssen WM, de Zeeuw D, Gans RO, de Jong PE: A central body fat distribution is related to renal function impairment, even in lean subjects. Am J Kidney Dis 2003;41:733-741.
9 Foster MC, Hwang SJ, Larson MG, Lichtman JH, Parikh NI, Vasan RS, Levy D, Fox CS: Overweight, obesity, and the development of stage 3 CKD: the Framingham Heart Study. Am J Kidney Dis 2008;52:39-48.

10 Kramer H, Luke A, Bidani A, Cao G, Cooper $\mathrm{R}, \mathrm{McGee} \mathrm{D}$ : Obesity and prevalent and incident CKD: the Hypertension Detection and Follow-Up Program. Am J Kidney Dis 2005; 46:587-594.

11 Chang A, Van HL, Jacobs DR Jr, Liu K, Muntner P, Newsome B, Shoham DA, Durazo-Arvizu R, Bibbins-Domingo K, Reis J, Kramer $\mathrm{H}$ : Lifestyle-related factors, obesity, and incident microalbuminuria: the CARDIA (Coronary Artery Risk Development in Young Adults) study. Am J Kidney Dis 2013;62:267275.

12 Ejerblad E, Fored CM, Lindblad P, Fryzek J, McLaughlin JK, Nyren O: Obesity and risk for chronic renal failure. J Am Soc Nephrol 2006; 17:1695-1702.

13 Gelber RP, Kurth T, Kausz AT, Manson JE, Buring JE, Levey AS, Gaziano JM: Association between body mass index and CKD in apparently healthy men. Am J Kidney Dis 2005; 46 : 871-880.

14 Lu JL, Molnar MZ, Naseer A, Mikkelsen MK, Kalantar-Zadeh K, Kovesdy CP: Association of age and BMI with kidney function and mortality: a cohort study. Lancet Diabetes Endocrinol 2015;3:704-714.

15 Munkhaugen J, Lydersen S, Wideroe TE, Hallan S: Prehypertension, obesity, and risk of kidney disease: 20-year follow-up of the HUNT I study in Norway. Am J Kidney Dis 2009;54:638-646.

16 Iseki K, Ikemiya Y, Kinjo K, Inoue T, Iseki C, Takishita S: Body mass index and the risk of development of end-stage renal disease in a screened cohort. Kidney Int 2004;65:18701876.

17 Vivante A, Golan E, Tzur D, Leiba A, Tirosh A, Skorecki K, Calderon-Margalit R: Body mass index in 1.2 million adolescents and risk for end-stage renal disease. Arch Intern Med 2012;172:1644-1650.

18 Hsu C, McCulloch C, Iribarren C, Darbinian J, Go A: Body mass index and risk for endstage renal disease. Ann Intern Med 2006; 144: 21-28.

19 Lu JL, Kalantar-Zadeh K, Ma JZ, Quarles LD, Kovesdy CP: Association of body mass index with outcomes in patients with CKD. J Am Soc Nephrol 2014;25:2088-2096.
20 Thoenes M, Reil JC, Khan BV, Bramlage P, Volpe M, Kirch W, Bohm M: Abdominal obesity is associated with microalbuminuria and an elevated cardiovascular risk profile in patients with hypertension. Vasc Health Risk Manag 2009;5:577-585.

21 Kramer H, Gutierrez OM, Judd SE, Muntner P, Warnock DG, Tanner RM, Panwar B, Shoham DA, McClellan W: Waist circumference, body mass index, and ESRD in the REGARDS (Reasons for Geographic and Racial Differences in Stroke) Study. Am J Kidney Dis 2016; 67:62-69.

22 Foster MC, Hwang SJ, Massaro JM, Hoffmann U, DeBoer IH, Robins SJ, Vasan RS, Fox CS: Association of subcutaneous and visceral adiposity with albuminuria: the Framingham Heart Study. Obesity (Silver Spring) 2011;19:1284-1289.

23 Postorino M, Marino C, Tripepi G, Zoccali C: Abdominal obesity and all-cause and cardiovascular mortality in end-stage renal disease. J Am Coll Cardiol 2009;53:1265-1272.

24 Kovesdy CP, Czira ME, Rudas A, Ujszaszi A, Rosivall L, Novak M, Kalantar-Zadeh K, Molnar MZ, Mucsi I: Body mass index, waist circumference and mortality in kidney transplant recipients. Am J Transplant 2010;10: 2644-2651.

25 Scales CD Jr, Smith AC, Hanley JM, Saigal CS: Prevalence of kidney stones in the United States. Eur Urol 2012;62:160-165.

26 Curhan GC, Willett WC, Rimm EB, Speizer FE, Stampfer MJ: Body size and risk of kidney stones. J Am Soc Nephrol 1998;9:1645-1652.

27 Taylor EN, Stampfer MJ, Curhan GC: Obesity, weight gain, and the risk of kidney stones. JAMA 2005;293:455-462.

28 Bhaskaran K, Douglas I, Forbes H, dos-Santos-Silva I, Leon DA, Smeeth L: Body-mass index and risk of 22 specific cancers: a population-based cohort study of 5.24 million UK adults. Lancet 2014;384:755-765.

29 Arnold M, Pandeya N, Byrnes G, Renehan AG, Stevens GA, Ezzati M, Ferlay J, Miranda JJ, Romieu I, Dikshit R, Forman D, Soerjomataram I: Global burden of cancer attributable to high body-mass index in 2012: a population-based study. Lancet Oncol 2015;16: $36-46$.

30 Renehan AG, Tyson M, Egger M, Heller RF, Zwahlen M: Body-mass index and incidence of cancer: a systematic review and meta-analysis of prospective observational studies. Lancet 2008;371:569-578. 
31 Bluher M: The distinction of metabolically "healthy" from "unhealthy" obese individuals. Curr Opin Lipidol 2010;21:38-43.

32 Sharma K: The link between obesity and albuminuria: adiponectin and podocyte dysfunction. Kidney Int 2009;76:145-148.

33 Wolf G, Ziyadeh FN: Leptin and renal fibrosis. Contrib Nephrol 2006;151:175-183.

34 Ellington AA, Malik AR, Klee GG, Turner ST Rule AD, Mosley TH Jr, Kullo IJ: Association of plasma resistin with glomerular filtration rate and albuminuria in hypertensive adults. Hypertension 2007;50:708-714.

35 Bastard JP, Maachi M, Lagathu C, Kim MJ, Caron M, Vidal H, Capeau J, Feve B: Recent advances in the relationship between obesity, inflammation, and insulin resistance. Eur Cytokine Netw 2006;17:4-12.

36 Furukawa S, Fujita T, Shimabukuro M, Iwaki M, Yamada Y, Nakajima Y, Nakayama O, Makishima M, Matsuda M, Shimomura I: Increased oxidative stress in obesity and its impact on metabolic syndrome. J Clin Invest 2004;114:1752-1761.

37 Ruan XZ, Varghese Z, Moorhead JF: An update on the lipid nephrotoxicity hypothesis. Nat Rev Nephrol 2009;5:713-721.

38 Ruster C, Wolf G: The role of the renin-angiotensin-aldosterone system in obesity-related renal diseases. Semin Nephrol 2013;33: 44-53.

39 Oterdoom LH, de Vries AP, Gansevoort RT, de Jong PE, Gans RO, Bakker SJ: Fasting insulin modifies the relation between age and renal function. Nephrol Dial Transplant 2007; 22:1587-1592.

40 Reaven GM: Banting lecture 1988. Role of insulin resistance in human disease. Diabetes 1988;37:1595-1607.

41 Kambham N, Markowitz GS, Valeri AM, Lin J, D’Agati VD: Obesity-related glomerulopathy: an emerging epidemic. Kidney Int 2001; 59:1498-1509.

42 de Vries AP, Ruggenenti P, Ruan XZ, Praga M, Cruzado JM, Bajema IM, D'Agati VD, Lamb HJ, Pongrac BD, Hojs R, Abbate M, Rodriquez R, Mogensen CE, Porrini E: Fatty kidney: emerging role of ectopic lipid in obesityrelated renal disease. Lancet Diabetes Endocrinol 2014;2:417-426.

43 Foster MC, Hwang SI, Porter SA, Massaro JM, Hoffmann U, Fox CS: Fatty kidney, hypertension, and chronic kidney disease: the Framingham Heart Study. Hypertension 2011;58: 784-790.

44 Henegar JR, Bigler SA, Henegar LK, Tyagi SC, Hall JE: Functional and structural changes in the kidney in the early stages of obesity. J Am Soc Nephrol 2001;12:1211-1217.

45 Knight SF, Quigley JE, Yuan J, Roy SS, Elmarakby A, Imig JD: Endothelial dysfunction and the development of renal injury in spontaneously hypertensive rats fed a high-fat diet. Hypertension 2008;51:352-359.

46 Tsuboi N, Utsunomiya Y, Kanzaki G, Koike K, Ikegami M, Kawamura T, Hosoya T: Low glomerular density with glomerulomegaly in obesity-related glomerulopathy. Clin J Am Soc Nephrol 2012;7:735-741.

47 Ribstein J, du Cailar G, Mimran A: Combined renal effects of overweight and hypertension. Hypertension 1995;26:610-615.

48 Maalouf NM, Sakhaee K, Parks JH, Coe FL, Adams-Huet B, Pak CY: Association of urinary $\mathrm{pH}$ with body weight in nephrolithiasis. Kidney Int 2004;65:1422-1425.

49 Lemann J Jr, Pleuss JA, Worcester EM, Hornick L, Schrab D, Hoffmann RG: Urinary oxalate excretion increases with body size and decreases with increasing dietary calcium intake among healthy adults. Kidney Int 1996; 49:200-208.

50 Siener R, Glatz S, Nicolay C, Hesse A: The role of overweight and obesity in calcium oxalate stone formation. Obes Res 2004;12:106-113.

51 Taylor EN, Stampfer MJ, Curhan GC: Diabetes mellitus and the risk of nephrolithiasis. Kidney Int 2005;68:1230-1235.

52 Klisic J, Hu MC, Nief V, Reyes L, Fuster D, Moe OW, Ambuhl PM: Insulin activates $\mathrm{Na}^{+}$ $\mathrm{H}^{+}$exchanger 3: biphasic response and glucocorticoid dependence. Am J Physiol Renal Physiol 2002;283:F532-F539.

53 Chobanian MC, Hammerman MR: Insulin stimulates ammoniagenesis in canine renal proximal tubular segments. Am J Physiol 1987;253:F1171-F1177.

54 Daudon M, Lacour B, Jungers P: Influence of body size on urinary stone composition in men and women. Urol Res 2006;34:193199.

55 Sinha MK, Collazo-Clavell ML, Rule A, Milliner DS, Nelson W, Sarr MG, Kumar R, Lieske JC: Hyperoxaluric nephrolithiasis is a complication of Roux-en-Y gastric bypass surgery. Kidney Int 2007;72:100-107.

56 Calle EE, Kaaks R: Overweight, obesity and cancer: epidemiological evidence and proposed mechanisms. Nat Rev Cancer 2004;4: 579-591.

57 Dalamaga M, Diakopoulos KN, Mantzoros CS: The role of adiponectin in cancer: a review of current evidence. Endocr Rev 2012;33:547594.

58 Lamas O, Marti A, Martinez JA: Obesity and immunocompetence. Eur J Clin Nutr 2002; 56(suppl 3):S42-S45.

59 Lim C, Savan R: The role of the IL-22/IL-22R1 axis in cancer. Cytokine Growth Factor Rev 2014;25:257-271.

60 Grivennikov SI, Greten FR, Karin M: Immunity, inflammation, and cancer. Cell 2010; 140:883-899.

61 Kovesdy CP, Anderson JE, Kalantar-Zadeh K: Paradoxical association between body mass index and mortality in men with CKD not yet on dialysis. Am J Kidney Dis 2007;49:581591.

62 Kalantar-Zadeh K, Kuwae N, Wu DY, Shantouf RS, Fouque D, Anker SD, Block G, Kopple JD: Associations of body fat and its changes over time with quality of life and prospective mortality in hemodialysis patients. Am J Clin Nutr 2006;83:202-210.
63 Beddhu S, Pappas LM, Ramkumar N, Samore M: Effects of body size and body composition on survival in hemodialysis patients. J Am Soc Nephrol 2003;14:2366-2372.

64 Curtis JP, Selter JG, Wang Y, Rathore SS, Jovin IS, Jadbabaie F, Kosiborod M, Portnay EL, Sokol SI, Bader F, Krumholz HM: The obesity paradox: body mass index and outcomes in patients with heart failure. Arch Intern Med 2005; 165:55-61.

65 Wilson DO, Rogers RM, Wright EC, Anthonisen NR: Body weight in chronic obstructive pulmonary disease. The National Institutes of Health Intermittent Positive-Pressure Breathing Trial. Am Rev Respir Dis 1989;139: 1435-1438.

66 Escalante A, Haas RW, del Rincon I: Paradoxical effect of body mass index on survival in rheumatoid arthritis: role of comorbidity and systemic inflammation. Arch Intern Med 2005; 165:1624-1629.

67 Kalantar-Zadeh K, Kilpatrick RD, Kuwae N, Wu DY: Reverse epidemiology: a spurious hypothesis or a hardcore reality? Blood Purif 2005;23:57-63.

68 Noori N, Kopple JD, Kovesdy CP, Feroze U, Sim JJ, Murali SB, Luna A, Gomez M, Luna C, Bross R, Nissenson AR, Kalantar-Zadeh K: Mid-arm muscle circumference and quality of life and survival in maintenance hemodialysis patients. Clin J Am Soc Nephrol 2010;5: 2258-2268.

69 Dekker FW, de MR, van Dijk PC, Zoccali C, Jager KJ: Survival analysis: time-dependent effects and time-varying risk factors. Kidney Int 2008;74:994-997.

70 Snyder JJ, Foley RN, Gilbertson DT, Vonesh EF, Collins AJ: Body size and outcomes on peritoneal dialysis in the United States. Kidney Int 2003;64:1838-1844.

71 Lee PS, Sampath K, Karumanchi SA, Tamez $\mathrm{H}$, Bhan I, Isakova T, Gutierrez OM, Wolf M, Chang Y, Stossel TP, Thadhani R: Plasma gelsolin and circulating actin correlate with hemodialysis mortality. J Am Soc Nephrol 2009; 20:1140-1148.

72 Horwich TB, Fonarow GC, Hamilton MA, MacLellan WR, Woo MA, Tillisch JH: The relationship between obesity and mortality in patients with heart failure. J Am Coll Cardiol 2001;38:789-795.

73 Stenvinkel P, Marchlewska A, Pecoits-Filho R, Heimburger O, Zhang Z, Hoff C, Holmes C, Axelsson J, Arvidsson S, Schalling M, Barany P, Lindholm B, Nordfors L: Adiponectin in renal disease: relationship to phenotype and genetic variation in the gene encoding adiponectin. Kidney Int 2004;65:274281.

74 Mohamed-Ali V, Goodrick S, Bulmer K, Holly JM, Yudkin JS, Coppack SW: Production of soluble tumor necrosis factor receptors by human subcutaneous adipose tissue in vivo. Am J Physiol 1999;277:E971-E975.

75 Rauchhaus M, Coats AJ, Anker SD: The endotoxin-lipoprotein hypothesis. Lancet 2000; 356:930-933. 
76 Jandacek RJ, Anderson N, Liu M, Zheng S, Yang Q, Tso P: Effects of yo-yo diet, caloric restriction, and olestra on tissue distribution of hexachlorobenzene. Am J Physiol Gastrointest Liver Physiol 2005;288:G292-G299.

77 Kramer HJ, Saranathan A, Luke A, DurazoArvizu RA, Guichan C, Hou S, Cooper R: Increasing body mass index and obesity in the incident ESRD population. J Am Soc Nephrol 2006;17:1453-1459.

78 Postorino M, Mancini E, D’Arrigo G, Marino C, Vilasi A, Tripepi G, Gallus S, Lugo A, Santoro A, Zoccali C: Body mass index trend in haemodialysis patients: the shift of nutritional disorders in two Italian regions. Nephrol Dial Transplant 2016;31:1699-1705.

79 World Health Organization: 2008-2013 Action Plan for the Global Strategy for the Prevention and Control of Noncommunicable Diseases. Geneva, World Health Organization, 2009.
80 O’Donoghue DJ, Stevens PE: A decade after the KDOQI CKD/guidelines: a perspective from the United Kingdom. Am J Kidney Dis 2012;60:740-742.

81 Bolignano D, Zoccali C: Effects of weight loss on renal function in obese CKD patients: a systematic review. Nephrol Dial Transplant 2013;28(suppl 4):iv82-iv98.

82 Chang Y, Ryu S, Choi Y, Zhang Y, Cho J, Kwon MJ, Hyun YY, Lee KB, Kim H, Jung HS, Yun KE, Ahn J, Rampal S, Zhao D, Suh BS, Chung EC, Shin H, Pastor-Barriuso R, Guallar E: Metabolically healthy obesity and development of chronic kidney disease: a cohort study. Ann Intern Med 2016;164:305-312.

83 Wing RR, Bolin P, Brancati FL, Bray GA, et al: Cardiovascular effects of intensive lifestyle intervention in type 2 diabetes. N Engl J Med 2013;369:145-154.

84 Mallamaci F, Ruggenenti P, Perna A, Leonardis D, Tripepi R, Tripepi G, Remuzzi G, Zoccali C: ACE inhibition is renoprotective among obese patients with proteinuria. J Am Soc Nephrol 2011;22:1122-1128.
85 Friedman AN, Wolfe B: Is bariatric surgery an effective treatment for type II diabetic kidney disease? Clin J Am Soc Nephrol 2016;11:528535.

86 Chang AR, Chen Y, Still C, Wood GC, Kirchner HL, Lewis M, Kramer H, Hartle JE, Carey D, Appel LJ, Grams ME: Bariatric surgery is associated with improvement in kidney outcomes. Kidney Int 2016;90:164-171.

87 Jamal MH, Corcelles R, Daigle CR, Rogula T, Kroh M, Schauer PR, Brethauer SA: Safety and effectiveness of bariatric surgery in dialysis patients and kidney transplantation candidates. Surg Obes Relat Dis 2015;11:419-423.

88 Ahmadi SF, Zahmatkesh G, Ahmadi E, Streja E, Rhee CM, Gillen DL, De Nicola L, Minutolo R, Ricardo AC, Kovesdy CP, KalantarZadeh K: Association of body mass index with clinical outcomes in non-dialysis-dependent chronic kidney disease: a systematic review and meta-analysis. Cardiorenal Med 2015;6: $37-49$. 